\title{
MY TURAKAWAEWAE: A REVIEW OF LEARNING
}

Ray O'Brien

\section{INTRODUCTION}

I have written this review of learning to meet the requirements of the first course of the Doctorate of Professional Practice (DProfPrac) through Capable NZ at Otago Polytechnic. As the first assessment the primary aim is to establish whether I have sufficient experience, skills and knowledge to progress into the later parts of the doctoral programme. In addition, my personal aims for the review are to (i) explore and articulate the influences and events that have shaped my professional growth to date and, (ii) to provide a line in the sand on which to reflect during the next three years of study.

The review has three parts. The first is a narrative of a short journey in my home area which relates my interpretation of environmental and cultural contexts of the area, to my past and my identity. The narrative of the first section is not intended to form a review of learning in its own right, but rather provide context, themes, examples and a data sources for the second part. It is deliberately not referenced or written in accordance with academic tradition. The second part is a critical evaluation of the extent to which the narrative supports that I am sufficiently experienced, skilled and knowledgeable to progress into the later parts of the doctoral programme. In the second part I use a more conventionally recognisable academic style. The third part is a future focussed reflection on the first two parts.

The first two section are deliberately juxtaposed with contrasting styles and formatting. This is partly to demonstrate versatility, but also as a challenge - a descriptive narrative is quite far from my default style of communicating through text. The third section is a reflection that moves away from the polarised styles of the first two sections towards a voice through which I could write the narrative of my professional growth in the doctoral programme. I see this process of finding an authentic voice as an important development in my professional framework of practice.

I invite you to walk with me through my narrative reflection, and to cast your critical eye over the discourse of the evaluation.

\section{PART ONE: A PERSONAL NARRATIVE IN MY TURAKAWAEWAE}

\section{Walking the Talk}

Every journey needs to allow time to stop and look around. A time to look back on the paths trodden, to check your location and to plan for the route ahead. Educational journeys are no different. The winding path of experiential learning weaves its way through a landscape of knowledge, understanding and capabilities. You can find yourself breathlessly climbing the steepest slopes, or shivering from fording the fastest rivers in the deepest gorges. This type of learning can be an unforgiving and time consuming route. 
It is easy to get lost. You can be blown off course by the storms of conflict, disorientated by a mist of stress or lost in a forest not knowing which path is the one you want. For this reason, it is important to take advantage of opportunities to recover, to get to know your landscape, triangulate your position from what you know, and listen to the stories that are shared along the way. You need to take time to review what you have learned from the encounters you had planned, and those that you had not.

It is a review of my learning that I am sharing with you here. This is a time for me to take stock of my journey so far, understand its significance to where I am today, confirm the direction I want to travel, and prepare for the next arduous leg of the trip. The next leg may be difficult to navigate. I am an educator and a generalist. As a result, I have a broad range of experiences that currently do not seem, on the surface, to link together. I have followed parallel professional streams of education, innovation, and purpose seeking. I think they all flow into the same direction, but I have not yet found their confluence so cannot be sure.

This review is set in the narrative of conversation and encounters around Otago Harbour, near Dunedin in the South Island of New Zealand. It is the landscape where I now live, where my whānau are growing up, where I work and play. Before I describe my time spent reflecting in this landscape, I should introduce myself properly.

Tēnā Koutou.

Ko Te Rotopāteke te tūrakawaewae.

I tipu ake au ki Scotland.

Ko Mount Brandan te mauka.

Ko Lee te awa.

Ko Atlanti te moana.

Ko Celtic te iwi.

Ko Dalcassian te hapu.

Ko Brian Broru te tino tipuna.

Ko Galarus Oritory te marae.

Ko O’Brien rātou ko Gibson ko Hislop ko Auchterlonie kā whānau.

Ko au tēnei.

Ko Ray O'Brien tōku ikoa.

Nō reira, tēnā koutou katoa.

\section{Setting Off}

There are handful of cars in the rough gravel carpark next to the small ferry jetty. As I walk across the carpark the clunk of the car locking is behind me. One door does not lock and I will never get round to fixing it. There are left over snacks on the foot mats, mud on the seats, and grime on the windows (at least I don't need to worry about it getting stolen). This is the pragmatism that I bring to most of my life and work - it works, it gets me where I want to be. It lets me focus on doing more things or visiting more places. The car is parked two spaces from a smart new black SUV. It belongs to a great family who I know and respect, but I reject the materialism and hierarchy that the car implies. I left those symbols behind with my UK passport when I decided that New Zealand was to be my turakawaewae and where my whānau would grow.

An extended family of Silvereyes flock from a Kowhai tree to more densely leaved pine tree. Their agitated calls break the calm of the still winter morning, echoing out across the water as if thrown into it like handful of gravel. The reason for their angst becomes clear as a Kāhu glides over-head casting his sharp eyes from side to side, tracing the line of the road side plantings. 
The fingers of his wingtips make regal gestures to swiftly and precisely adjust his flight. This noble gesture did not go unnoticed in years past. One whakatauki suggests that because of their nobility ko te kāhu te whakaora, waiho kia rere ana (that the kāhu should be saved and allowed to fly on). This is described in stark contrast to the Kārearea who was to be snared for being betrayed by their swift and agile flight as being bold and treacherous - Homai te kāeaea kia toro-māhangatia. No noble ending was is store for the Kārearea.

Homai te kāeaea kia toro-māhangatia

Ko te kāhu te whakaora - waiho kia rere ana!

The kārearea must be snared

And the kāhu saved - let it fly on!

Retrieved from Te Ara - The Encyclopedia of New Zealand. Original source not known.

My encounter with the Kahu is not my only light brush with such nobility. Brian Boru te tino tipuna, was crowned king of all Ireland in 1004. His descendants became the Ui Brian (O'Brien). He was born into a newly emerging tribe known as the Dalcassians around 940 AD in what is now County Clare. From there he had the benefit of living near and interacting with Viking settlers. He used the knowledge of new weapons and better boats to carry out river-raids in quest to rule Munster. He was a relationship builder, an innovator, a collaborator an early adopter. His later claim to control all of Ireland was challenged by the Norse invaders and Leinster men alike. Ultimately, he led the Munster troops to victory in the battle of Clontarf (I014 AD). But he paid a high price for this success. Brian, his son and grandson all died in the battle.

What sort of leader was he? Was he a kāhu or a Kārearea? He seems to have swooped with agility in the changing times rather than flying steady in the winds of change. Pondering my own sense of being a leader, I'm not sure which I would have preferred my distant ancestor to be. The Kārearea flying boldly close to the cliffs with rapid changes of direction is more in line with the agility I aspire to. I ponder whether my flightiness is viewed by some with the same distrust as the Kārearea met. Did King Brian's tendency to maximise on relationships, innovation and being an early adopter somehow make its way to me through the generations?

As the Kāhu rounds the corner and out of sight, my attention is drawn to the water, as a boat engine thumps into life. One thing is for sure, the engine is much better at winter mornings than I am. I head off to the water taxi that will take me to Kamau Taurua or as the Scottish Presbyterians labelled it, Quarantine Island.

\section{Don't Pay the Ferryman?}

From the rear deck of the ferry I can look down into the strong tidal flow that separates the geometrical 1980s architecture of the University Marine Research Centre from the old colonial buildings of the island. The water drawn in from the ocean to fill the harbour pushes through rocks and over shallows creating waves and swirls that dissipate as they pass the island and enter the safer waters of the harbour - the harbour is taking its twice daily deep breath. Downstream a seal pops his broad nose above the water for no more than a glance. A moment later his preoccupation becomes apparent. A loud slap draws our attention to the seal thrashing his head on the water. Kekeno the seal had a tasty prize - an octopus. The brutality of his attack tears all of my thoughts way from the tranquillity of the sea washing the rocks. Te Wheke is being torn apart limb by limb. It is an unjust end for such an intelligent animal and is heavily laden with sad irony as he is so often used as a kaupapa Māori metaphor for health. Kekeno does not seem to need to accommodate this injustice, nor the metaphor.

The harbour is alive and has provided for many more than Kekeno for a long time. The depths and the shallows have provided sustenance for Māori since they first explored the area in 9th century.

As Tahu Potiki describes: 
The Otago Harbour is a site of singular importance to the KaiTahu, Kati Mamoe, and Waitaha people of this district. It has been a source of nourishment, a major highway, a sheltering location for human settlement, a burial place and a symbol carrying the ancestral, spiritual and religious traditions of all the generations prior to European settlement.

(Tahu Potiki, Te Runanga o Otakou, submission regarding 'Project next Generation' on the harbour 201 I retrieved from http://quarantineisland.org.nz)

While the water provided kai moana, the bush provided both food and medicine aplenty. Behind me rises the cone of Here Weka. While this hill casts its shadows and reflecting onto the same bays and islands as it did when the Kati Mamoe first arrived, today it manages no more than a stubble of the rich vegetation with which it was once adorned. It is a distinctive remnant of the volcanic history of the landscape, a bookmark for those, like myself, becoming acquainted with the Otago Peninsula. It is the mauka to which my son relates.

On the other side of the globe Ventry Bay in County Kerry has a similar geological history, morphology and significance. Standing over the waters of Ventry Bay, Mount Brendan casts its shadow. - Ko Mount Brendan te mauka. Its namesake is St Brendan the navigator. St Brendan his disciples reputedly set sail sometime around 500AD from the very shores on which my great grandfather played as a boy. They voyaged for several years, discovering sea monsters and sailing past a hell where the fires rolled into the sea and several of the crew were overcome by the stench (possibly modern-day volcanic Iceland). Their ultimate objective were the Isles of the Blessed - also known as the Fortunate Isles - a collection of islands in the Atlantic Ocean, near to North America. It seems he did set foot there at some point. They took refuge one night on an island. When they set a fire to keep themselves warm the whole island sank. - it was a whale. Brendan's story lives in Irish folklore, Norse saga, and Roman legend.

Around the same time Maui and his crew were navigating the shores of the whenua-teitei that the long white cloud had drawn them to. They also encountered taniwha and kewa. They were following the migration of the kewa, one of the many navigation tools available to explorers in those days. Maui's story lives in Māori tradition, it varies from iwi to iwi, and from pacific island to pacific island. It may be that over the centuries there have been many Mauis who now belong to the same story retold in many places, like a Viking saga of the south.

Like the rocks over which the tides pass, our stories have survived by taking their shape from the gradual washing of time. How do we understand what is true through the lens of our today, with our yesterday being so open to interpretation?

\section{Banter on the Beach}

As I disembark and wander down the old creaky jetty past the hulks of decaying boats, a kayak arrives in the enclosed bay. As it reaches the rocky beach the kayaker, seemingly without thinking, tilts the boat far to one side and curves the hull around landing carefully and gently on the rocks without damage. A small wave scurries away from him niggling the jagged rocks of the beach as it goes. We greet each other, and he seems as surprised as I am to hear how similar our accents are. A west coast Scottish rolling "rrr" is unmistakable. He sits on a rock near his kayak and I dangle my legs from the jetty. I am curious. Who is he? How did he get here? With common ground established, we start a conversation.

"That's a fairly unusual paddle you've got" I say.

"Yes, it's a Greenland-style Paddle." His reply rolls off his tongue, like a well-practiced elevator pitch, He seems to welcome the interest and continues. "It's great for long distances and windy conditions. The Greenlanders use this style partly because they couldn't make fancy carbon blades, but mainly because it was better for hunting with".

"Have you kayaked in Greenland?" I ask. 
The kayaker obliges, keen to tell me more of himself."Yes. I went to compete in the Greenland Kayak Games. It was a really special thing. I've spent most of my adult life sitting in a kayak for work and for play. I work with the military, training leaders through outdoor activities, so get into some fairly challenging situations. That trip was so different. There is such a strong link between kayaks and the Inuit that there was a whole other layer to understand".

"There was also this thing going on in our heads about colonialism. Although it is Denmark governs Greenland, we were there on a Winston Churchill Scholarship. I had to wear a suit and meet two of his grandchildren for an interview in some posh club in London - it didn't feel very Braveheart!" We both laugh. The irony of how Mel Gibson has become such a non-Scottish Scottish icon, isn't missed on a Scotsman. Perhaps it's the ultimate form of colonisation in its own right.

Having satisfied his need to share what he had done, the kayaker asks what I do for a job. His reciprocation of interest is welcome, but the question he asks betrays the fact that he has not been in New Zealand for very long. Even the least useful of expat websites will tell you that asking that typically British question before getting to know the person shouts in screaming LED lights that you have just stepped off the waka - which he has.

When I say that I am a lecturer at a local polytechnic, he raises his eyebrows and nods slowly. It's a show of cynicism that he makes little attempt to hide. "An academic?" he states, more as an accusation than a question. If the conversation has been egalitarian until now, his cautious response changes the mood slightly.

"Some might say pracademic," I say, as a form of confession, "but I think you might as well own up to it. You sound like you've got some thoughts on academia?"' "Well it's not the real world is it?" he responds.

I shrug my shoulders, in partial agreement. I want to explain how relevant academia and tertiary education can be, but the words floating around my head all seem to reinforce his point. Heutagogy. Future focussed. Selfdetermination. Transformation. Emancipatory. It's become a conversation I am familiar with.

My father's career took him from a tradesman to corporate trainer and played a part in an economic development agency. He was a man with a catholic hard work ethic and an old-labour unionised sense of knowing through doing and lived experience. These were the traits that carried him through. As I am the first in my family to study at a tertiary level I am supposedly at more risk of academic failure than others. However, I am my father's son. I am grounded with a critical mind-set that has given me license and confidence to challenge the assumed reality and wisdom of education. It may also explain why it has taken me to now, at the level of doctorate and to professional practice learning before feeling strong alignment with the process of education.

Without saying so much, we agree to both agree and differ on the relevance of academia. I wish him well and leave him to the beach. I take a steep path that cuts its route across the hill towards the remaining buildings of the Old Quarantine Station.

\section{Flue with a View}

Quarantine is a strange concept. From the high point of the island I find an old chimney breast silhouetted against the skyline. It bends into the wind; an old woman, wrapped in a shawl, expectantly looking out to sea. It is the last part of the old hospital. The remaining pieces of a 200+ year story. In the late 1800 s Pākehā setters - after weeks on the ocean in tortuous conditions - were forced by the powers of the day to spend time on the island to ensure that their diseases did not land in their home to be. More than 70 of these visitors never left the island. Restricted to their hospital beds by their illness, with the smell of the harbour blowing through the windows. They had only to stand to find a view where the home they had dreamt of for so long cruelly taunted them. The nearby cemetery is a sober reminder of their passing. While many graves are unmarked, the tiny pillows of grass provide a reminder of the sadness that many young couples would have taken to their new Otago homes. For me it is a reminder that some memories are best left buried and forgotten. The pain of reflection does not justify the gain. 
I sit by the chimney to consider my journey and how to navigate the next leg of it. I too travelled across the planet with my whanau seeking a new life. We have made this landscape before me our home. I am also to some extent in a type of quarantine - proving my fitness and health to progress to the next step of this doctoral qualification While this prays on my mind for a while, in this setting, the trials of an academic process or the possible outcomes, seem trivial in comparison those which the hardy Presbyterian travellers from so long ago faced. "Ifl've made it this far" I can hear them say.

Like it has for me, this landscape and its communities continue to provide shelter for weary travellers from all around the globe. While most of the immigrants now arrive in search of an even better life than the one they enjoyed elsewhere, some still come to escape the horrors of war, famine and persecution. Today, they are mostly greeted with open arms. But the feeling of arriving on these shores - bodies aching, minds fearful - has not been lost through the generations.

This concept of welcoming - of being open to all, of being willing to make a difference - is core to my work and life. It was not long ago that I was holding a new born child of recently arrived Syrian refugees. It was without doubt the strongest symbol of infinite hope I have ever experienced. A feeling I am sure would have been familiar to many of the Scots who settled here in the 1800s.

\section{Homeward bound}

I leave the kuia to her lonesome vigil and take a walk around the island. A new path guides me through both regenerating forests and sheep clipped fields. With my hair and my lungs full of the harbour breeze, I make my way back down to the ferry, waiting for me at the jetty.

From a seat at the rear of the deck, it is clear that the waves and swirls have now disappeared as the tide makes its twice-daily change of mind and the boat enjoys the respite of slack water.The rusty cliffs of the island and the slow dancing clouds above are reflected in the stillness of the water. Standing on the boat in the harbour, the relationship between the changing tide, the still weather, and the gravity of the sun and moon, seems tenuous at best. The change is however conspicuous and the relationship strong.

The ferry draws alongside all too soon. I reluctantly step into the jetty. The relationship between the landscape and the busyness of family and work, sometimes feels uncomfortable. Like walking in well fitted but odd shoes. It is a relationship that has changed over time and will continue to - it waxes and wanes and ebbs and flows. The change is subtle but conspicuous and the relationship strong. It is complex and I know it - this is my Turakawaewae. 


\section{PART TWO: CRITICAL EVALUATION OF NARRATIVE}

In this second section of the review of learning, the extent to which the narrative in the first section supports that the author is sufficiently experienced, skilled and knowledgeable to progress into the later parts of the doctoral programme is critically evaluated.

Critical evaluation can be interpreted in many ways in different contexts, therefore it is important to clarify how it applies to the author's context before proceeding. The root of the word critical can be found in the Greek crit which refers to separating or choosing (Michigan State University, n.d.) and évaluation (French) refers to prescribing value or merit (Online Etymology Dictionary, n.d.). Therefore, critical evaluation can be considered a process of separating in order to place a value. Within the author's tertiary education context this reductionist approach of separating in order to ascribe value is at the heart of a significant tension (Ings, 20 I7). The reduction of learning into smaller units in order to assess merit has the potential to diminish the perceived value of understanding the whole (Freire, 1998). The critical evaluation of the narrative, carries that tension between holism and reductionism, giving value to both micro and macro elements. The dualism in this is valued by the researcher throughout.

Dualism is reflected in the structure of this section. The extent to which the narrative describes how the author's specific experience, knowledge and skills will support them in their doctoral study is evaluated first. Supplementary information is provided where the narrative falls short. Then, the extent to which the narrative describes the paradigm through which the author will approach doctoral study is evaluated. This evaluation examines the text of the narrative through the structures of four characteristics of paradigm: epistemology, ontology, axiology and methodology. It is expected that to conduct professional practice research at a doctoral level the author should be acutely aware of the paradigm through which they view their research. A conclusion is then provided that incorporates both specific and holistic aspects of the author's capabilities.

\section{The author's experience, skills and knowledge}

To critically evaluate the author's skills, knowledge and experience, it is important to clarify the evaluative criteria against which they are being evaluated. The aim of the DProfPrac at Otago Polytechnic is for candidates to "create new knowledge that will advance practice" (Otago Polytechnic, 20 I 6, p. I). In this case the advancement in practice will be focussed on the author's own professional practice, and as such is strongly aligned with an auto-ethnographic approach (Holt, 2003). The focussed critical question is therefore, to what extent does the narrative demonstrate that the author's professional and research experience, skills and knowledge are suitable for conducting autoethnographic research in the context of work based learning at a doctoral level?

As the narrative describes a short journey through the author's local geography, it would have been detrimental to both flow and authenticity to exhaustively describe the research and professional knowledge of the author. While some specific writing skills are demonstrated and some personal experiences referred to, the narrative more adequately demonstrates, through implication, the worldview or paradigm through which the author interprets research and professional experiences in order to build knowledge. While this is a strength of an auto-ethnographic approach, it is necessary to supplement the narrative with an evaluation of the suitability of the knowledge, skills and experience gained through the author's research and professional roles.

While the author's research experience is commensurate with that of an emergent researcher, there has been a range of roles undertaken in a relatively short time frame. Creswell (20I2) presents two roles a researcher may assume when observing ethnographic research; the non-participative observer and the participative observer. The author has previously conducted and published research as a non-participative observer some of which examining the author's field of practice (Boyle, O'Brien, \& Sellar, 20 I 8; Collins \& O'Brien, 20I6). In O'Brien (20I6) the author's own practice and work place was excluded in an attempt to increase objectivity. The author also has experience of conducting and publishing research on their own practice in the role of a participant observer (Mann, Ker, Eden- 
Mann, \& O'Brien, 2017a, 2017c; O'Brien, 8,94I20 I8a). However, even a participating observer's role does not fully align with a researcher's role in an auto-ethnographic approach; being the observer, the participant and the subject (Chang, 2008). Both O'Brien, (20 I8b) and O'Brien (20I8c), are examples of the author stepping into an emerging role as an auto-ethnographic researcher. This emerging role is fully supported by extensive professional knowledge.

The author's professional capabilities have been developed through formal training and qualifications across a range of professional contexts, and from a range of tertiary institutions and training roles. The majority of these qualifications have been undertaken while in full time work and were fully integrated into the author's work. The author's current role involves the evidence based development and delivery of new and innovative practice which is creating new knowledge and advancing practice. This professional knowledge is fully integrated with the research knowledge described above; all research activity directly related to or influenced the author's practice. How new knowledge is assimilated into our schema shapes our view of the world and the action we then take (Syed, 20I5). Therefore, it is necessary to evaluate the extent to which the narrative demonstrates that the author is sufficiently aware of the paradigm they bring to their professional and research roles.

\section{The author's world view}

While Kuhn (1970) provided very specific criteria to define a paradigm, more contemporarily it is seen as "simply an acceptable worldview" (Mackinnon \& Powell, 2008, p. 24). As has been the tradition in educational research, a more contemporary and open description of paradigm has been adopted to unpack the world view implied in the narrative (Donmoyer, 2006).

Guba and Lincoln (2005) described the concept of paradigm, as it applies to research, as having four main elements: epistemology, ontology, axiology and methodology. Kivunja \& Kuyini (2017) explain how these key aspects of research paradigms relate to education research. As Illustrated in figure I, the same four key elements can be used to unpack the paradigm described in the narrative.

\section{Epistemology}

Epistemology is concerned with the basis of knowledge and justified belief (Dudovskiy, 20 I 8b). The narrative implies a constructivist epistemology through the metaphor of learning as a journey- knowledge being constructing from the experience of the journey. Ültanır (20I2) describes the basis of constructivism as the idea that development of understanding requires

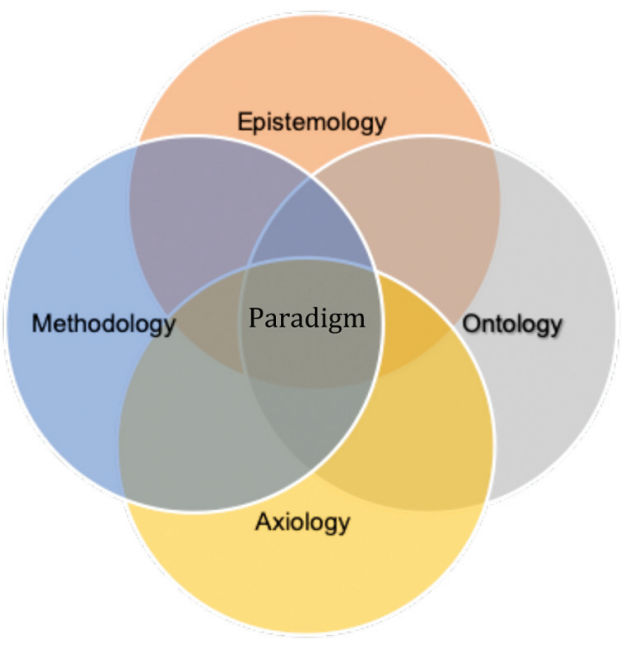

Figure 1. The four elements of paradigm. upon active engagement in meaning-making. It is an integration of, landscape, family, culture, people, history and present to construct knowledge and an understanding of place. It is an interaction of thinking with experience. This is supported by specific examples in the narrative. For example, the claim that a pragmatic approach is adopted in order to focus in doing more things or visiting more places. This value on learning through experience is also embedded in the description of the author's ancestors from an ancient relative, learning new battle skills through interactions with Vikings, to the hands-on sense of knowing demonstrated by the author's father. A constructivist epistemology is clearly a central element of the author's world view. 


\section{Ontology}

Ontology is concerned with the assumptions we make in order to believe that something is real. Baghramian and Carter (2018) describe a relativist ontology as being in tension with concepts of absolutism, objectivism, monism and realism. The narrative suggests the author's alignment with a relativist ontology through implied tensions with all four concepts as follows.

Rather than demonstrating a belief in one absolute truth or value-set, the narrative demonstrates relative truth and value. For example, relative to time, truth and values are seen to change, such as describing the values of the author's ancestors including his father. A fictitious conversation with the author's younger self on the beach specifically related to a changing professional identity or sense of being specific to a time and place rather than being absolute. The shifting of truth and value through time is also metaphorically described through the changing of the tide and how it interacts with the rocks of the harbour.

The narrative provides several examples of subjectivism being valued over objectivism. For example, when the author questions other peoples' perceptions of his flightiness. The questioning shows that the author's sense of being or identity is subject to interpretation by others and he is not an independent agent. Another example, is the symbolic reference to the author giving away their passport and changing how they approach the task of getting to know another person through a new cultural lens. The interpretation of identity is subject to changing cultural values and context rather than being an objective process.

The narrative is a three dimensional description. It is not, as Sousanis (2015) describes, a flatland of monism where everything can only be viewed from one perspective. The author values pluralism over monism in two specific cases. Plurality can be found in the conversation on the beach in the plurality of the author's sense of identity as an academic. This is a tension between what is traditionally seen as the identity of an academic and the author's more contemporary and practice based interpretation. Another layer that the narrative unflattens is the relationship between the author and Te Ao Māori. While the author does not identify as iwi Māori, the narrative provides many examples of how Māori knowledge and world views have been integrated both in practice and in identity. For example, the author has integrated the use of Te Reo Māori into the narrative without providing direct translations. This is based on the expectation that the reader will anticipate and value the integration. In some cases the Te Reo Māori word and the English word have been alternated. The use of Te Wheki or Octopus and the description of the old woman or kuia are two examples. This is not merely a switching of vocabulary from one language to another, the words are sufficiently culturally loaded to create the opportunity to interpret the scene with some understanding from more than one cultural standpoint. The author introducing themselves through a mihi, relating observations of nature to a traditional whakatauki, and drawing parallels between the historical stories of Māori ancestors and the author's ancestors, are further examples of a culturally plural approach to interpreting what is real.

The last of the four concepts described as being in tension with a relativist ontology is realism. While this has strong links to the concept of pluralism described above, the narrative provides examples of the author recognising that there can be several concurrent versions of reality in the same situation, rather than a singular and objective truth. There are several realities that run to some extent in parallel within the narrative. The historical accounts of Maui and St Brendan run in parallel and themselves have other branching truths, such as different versions of the stories in many different cultures and languages around the world. Where realism encourages seeking one singular truth, the narrative accepts the parallel truths and interpretations. A specific example of this is the dates that have been used to place these stories in history. The date of St Brendan's voyage was based on accounts written by monks several centuries after the voyage. The dates for Maui's voyage are based on counting back through generations of a whakapapa using 20 years as an average generational gap. Neither approach has been described in the narrative as more accurate of valid - both are based in parallel cultural realities.

Given the examples above, the narrative strongly indicates that the author has adopted a relativist ontology that accepts relative truths or values, subjectivism, pluralism and multiple accepted realities over absolutism, objectivism, monism and realism. 


\section{Axiology}

Axiology is concerned with concepts of value (Dudovskiy, 2018a). In the context of research axiology relates specifically to decisions based on ethical or aesthetic values (O'Gorman \& Maclntosh, 20I5). This is quite different from the ethical considerations and processes relevant to specific research activities. Axiology is a meta-ethical view of the world. The narrative implies the author has assumed a position of axiological naturalism aligned with the work of Dewey (as cited in Hart, 197I). Naturalism supports both ethical and aesthetic value being assigned through an interlinked relationship between feelings, interests, desires and experiences which is not seen as fixed in time but expected to evolve. The following examples describe how the narrative implies the value placed on equity, wellbeing and indigenous rights within the author's worldview.

Equity is a guiding value for the author. The statement rejecting an expensive car as a symbol of materialism and hierarchy is one example. Behind the rejection are relationships between past experiences, moving from one country to another and the family who own the car. A high value is placed on wellbeing. This is seen in the author's self-care in not reflecting on experiences which are too painful to justify the possible learning, and in the author's discomfort at observing the brutal attack on the octopus. Behind the value placed on wellbeing are relationships between family, experiences, wildlife and a sense of place. Throughout the narrative the author refers to Māori indigenous knowledge. In fictitious conversation with the author's younger self, reference is made to the importance of Inuit culture around kayaking. Placing such a high value on indigenous understandings is a result of dynamic relationships between the author, the natural environment, traditional stories, interpretation of the Treaty of Waitangi and personal connections.

Axiology is not only concerned with values that guide decisions and actions of the researcher, but also relate to the expected outcomes of the research i.e. does the research result merely in increased understanding or does it actually make a difference (Kivunja \& Kuyini, 2017)? The value placed on practical application, groundedness, and making a difference is explicitly stated as core to the author's life and work as a pracademic (Posner, 2009).

Given the examples above it is clear that the author is guided and influenced in their ethical and aesthetic decision making by values of equity, wellbeing, indigenous rights and the need to make a difference. These values being subject to change through time and complex relationships.

\section{Methodology}

Methodology is concerned with the research design, methods, approaches and procedures used in an investigation. Based on the design of the DProfPrac there are two levels of methodology to be considered; (i) the methodology used to develop the aspirational framework of practice (ii) the methodology used in each of the projects that create the knowledge which prompts an iteration of the aspirational framework of practice (Otago Polytechnic, 20I6).

As described already the author is subject, observer and participant. Ellis, Adams, \& Bochner (20I0) describe auto-ethnography as the systematic analysis of personal experience in order to understand cultural experience. Therefore an auto-ethnographic methodology is appropriate for the higher level methodology (Dyson, 2007). This can be further refined as aligning with the reflexive ethnography as it will document changes in the researcher as a result of conducting research (Ellis et al., 20I0). The iterative and practice based nature of the aspirational framework of practice align with the cyclical and problem solving focus of action research methodology fits well (Herr \& Anderson, 2014; Koshy, 2009). Thus, the overriding methodology is that of auto-ethnographic action research. The narrative thus becomes the first cycle of action research- based on experiences and informing the iteration of an early framework of practice.

For each of the action research cycles that contribute to the iteration of the aspirational framework of practice, a different methodological approach may be required. Indeed, the triangulation of varied methodologies not only aligns with a constructivist epistemology and a relativist ontology, it can also be seen to add explanatory power 
(Creswell, Hanson, Clark Plano, \& Morales, 2007; Joslin \& Müller, 20I6). Given the evidence of a constructivist epistemology, a relativist ontology, and an axiology guided by equity, wellbeing, indigenous rights and the need to make a difference, there are some methodologies that may align more strongly with the authors world view than others (Kivunja \& Kuyini, 2017). It should be noted that while some methodologies may be better aligned to the authors world view, there is no implication that others would be excluded.

Methodologies that align with the author's world view, as implied by the narrative include; Naturalist methodology (Guba \& Lincoln, 1982), Narrative inquiry (Mitchell \& Egudo, 2003), Case Study (Baxter \& Jack, 2008), Phenomenology (Tuohy, Cooney, Dowling, Murphy, \& Sixsmith, 20 I3), Ethnography (Hammersley, 20 I 8), Action Research (Coghlan \& Brannick, 20 I4; Herr \& Anderson, 20I4), Critical Discourse Analysis (Asghar, 20I3), Design Based Research (Barab \& Squire, 2004) and Futures Studies Methodologies (Inayatullah, n.d.; Ramos, 2002).

Therefore, although the narrative did not directly describe the methodological elements aligned with the author's world view, through inference from epistemology, ontology, and axiology and the design of the DProfPrac, a set of credible and well aligned methodologies has been identified.

\section{A pragmatic paradigm}

As described by Guba and Lincoln (2005) and Kivunja and Kuyini (2017) and illustrated in figure I, paradigm is influenced by four elements; epistemology, ontology, axiology and methodology. Each paradigm has a distinctive profile across the four elements. As Illustrated in figure 2, the narrative describes the author's constructivist epistemology, relativist ontology, and axiology guided by equity, wellbeing, indigenous rights and the need to make a difference. This profile is also well aligned with a range of mixed or qualitative methodologies. This profile implies an alignment with a pragmatic paradigm (O'Gorman \& Maclntosh, 20I5).

Core to pragmatic paradigm is the notion that "beliefs are guides to action and should be judged against outcomes rather than abstract principles" (Ormerod, 2006, p. I). Furthermore pragmatism

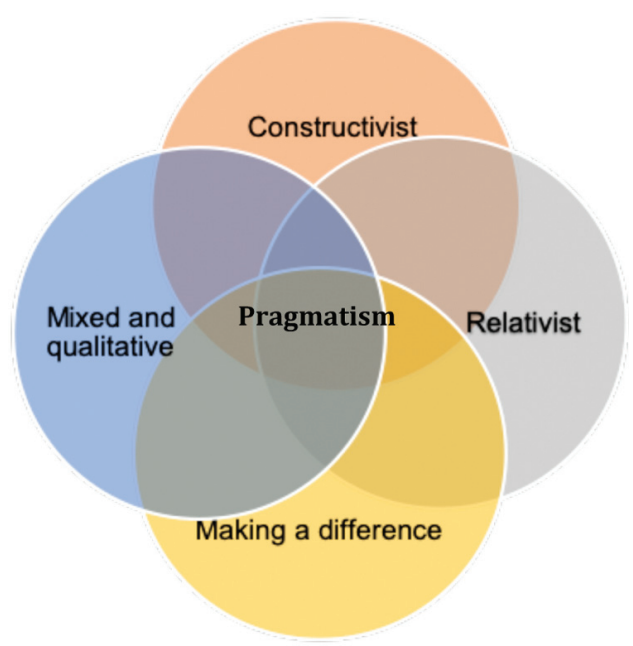

Figure 2. Elements of Pragmatic paradigm. serves practitioners well in that it; accepts the uncertainty and changing nature of findings; recognises the individual interpretation of meaning; accepts that inquiry and knowledge are social; supports learning based on experience; and is flexible enough to accommodate other paradigms (Ormerod, 2006). This final point being particularly significant as many if the features that have been used to describe elements of the authors world view would also support constructivist or interpretivist paradigms. For example, the characteristics of a constructivist epistemology clearly align with a constructivist paradigm and a relativist ontology aligns with an interpretivist paradigm. However, the over-arching need for practical outcomes that make a difference tips the balance towards pragmatism being a more appropriate description of the author's paradigm.

The adoption of a pragmatic paradigm is not only supported through implication from the four elements of paradigm, but also with direct reference in the narrative. For example, the pragmatism displayed by the author not being concerned about their car being left unlocked in fairly overt. The author embraces that they have been part of several parallel professional pathways that have not yet found their confluence. This indicates that they are not concerned about a perfect framework, but rather one that works. 
In conclusion, as pragmatic paradigm has been described through both direct reference and implication, it is reasonable to claim that the author is sufficiently aware of the paradigm through the way they view and interact with their professional and research roles, to continue in a path of doctoral studies.

\section{CONCLUSION}

The focussed critical question this evaluation addresses is: to what extent does the narrative demonstrate that the author's professional and research experience, skills and knowledge are suitable for conducting autoethnographic research in the context of work based learning at a doctoral level? New Zealand Qualifications Authority describe doctoral study as; producing knowledge at the most advanced frontier of a field of professional practice; conducting critical reflection on existing knowledge or practice and the creation of new knowledge; and demonstrating a sustained commitment to the professional integrity, and the development of new ideas or practices at the forefront of discipline or professional practice (New Zealand Qualifications Authority, 2016).

This question has been addressed from a reductionist perspective of looking at specific experience, skills and knowledge and from a holistic evaluation of the extent to which the author was aware of the paradigm through which they approach their research and professional roles.

The narrative did not fully describe the author's specific skills, knowledge and experience, so supplementary information was provided in appendices to provide adequate evidence that the author is capable of the research and professional roles expected of an emergent researcher at doctoral level.

The narrative was comprehensive in its description of paradigm both directly and through inference. This evaluation was structured in alignment with accepted philosophy traditions and research. Given the significance of paradigm in auto-ethnographic research, where the author is observer, participant and subject, a high level of awareness of the paradigm through which one views their professional context and research is important. The narrative supports that the author has such a level of self-awareness and would be well equipped to progress in doctoral study.

In conclusion, both specific and holistic analysis of the narrative and supplementary evidence support that the author is sufficiently skilled, experienced and knowledgeable to progress towards and Doctorate of Professional Practice. 


\section{PART THREE: REFLECTION}

\section{Three strong legs}

I have completed this review of learning in three stages. Firstly, writing a narrative of a short journey described through my own eyes. Secondly, writing a critical evaluation of the effectiveness of the narrative in demonstrating my readiness to continue along a doctoral pathway in professional practice, which adopts an auto-ethnographic action research approach. The third stage is this reflection on the significance of the learning in the first two stages.

Mezirow (199I as cited in Coghlan \& Brannick, 2014) describe action research as a three legged stool with content, process and premise as supporting legs. Upon reflection, I see that this review of learning has generated learning in all three of these aspects. Content learning has been addressed through evaluating specific skills, knowledge and experience. Process learning has been addressed through a novel and diverse writing experience. Premise learning has been addressed through describing and establishing my alignment with a pragmatic paradigm through which to approach professional practice and research.

Moving forward, the most significant aspect of this learning is the description and alignment of a pragmatic paradigm. There are four key reasons why this is significant learning for me:

- I am now more able to fully articulate the influence my paradigm has on how I interpret phenomenon.

- I can now be more confident in how I create understanding and knowledge, as my approach is legitimised through a recognised paradigm.

- I now have an increased awareness of the philosophical basis of differences I may need to navigate, when practicing or researching within a context where others may align with different paradigms.

- I now have an increased awareness of how my paradigm might influence the most appropriate methodologies for my research.

This is what Coghlan \& Brannick (20 I4) describe as actionable knowledge which is usable in practice, and theoretically robust from a scholarly perspective. It is knowledge that I will take into action as I progress in planning my research projects. It is knowledge that will support me in way-finding through the "messiness and unpredictability" of action research (Coghlan \& Brannick, 20I4, p. 83).

Ray O'Brien works across several areas at Otago Polytechnic, but at the core of all of them he is a learning designer. He has been part of the team designing and implementing the Bachelor of Leadership for Change and specialises in the integration of sustainable practice into programmes across many disciplines. 


\section{REFERENCES}

Asghar, J. (2013). Critical Paradigm: A Preamble for Novice Researchers. Life Science Journal, 10(4), 3121-3127. Retrieved from https://www.researchgate.net/publication/260675/35_Critical_Paradigm_A_Preamble_for_Novice_Researcher

Baghramian, M., \& Carter, J.A. (20 I 8). Relativism. In E. N. Zalta (Ed.), The Stanford Encyclopedia of Philosophy (Winter 20I8). Retrieved from https://plato.stanford.edu/archives/win20 I/entries/relativism/

Barab, S., \& Squire, K. (2004). Design-based Research : Putting a stake in the ground. The Journal of Learning Science, $13(1), 42$.

Baxter, P., \& Jack, S. (2008). Qualitative Case Study Methodology: Study Design and Implementation for Novice Researchers. Qual Rep, 13(4), 544-559.

Boyle, F., O'Brien, R., \& Sellar, S. (2018). A case study applying Mang and Rees's model of sustainability to organic waste processing. Scope-Contemporary Research Topics, Learning and Teaching 6, 51-59. Retrieved from https://www.thescopes.org/assets/ Uploads/5I-Scope-Learning-Teaching-6-Boyle-OBrien-Sellar.pdf

Brown, T., \& Wyatt, J. (2010). Design thinking for social innovation. Stanford Social Innovation Review Winter 2010, Winter, 30-35. Retrieved from https://ojs.unbc.ca/index.php/design/article/viewFile/I272/I 089

Chang, H. (2008). Autoethnography as a method. Retrieved from http://markfoster.net/struc/autoethnography.pdf

Coghlan, D., \& Brannick, T. (20 I4). Doing action research in your own organisation (4th ed.). Retrieved from http://2 I 3.55.83.2। 4:8 I 8 I/ Education/27492.pdf

Collins, E., \& O'Brien, R. (2016). Highly Structured ePortfolio Platform for Bachelor of Nursing Students: Lessons Learned in Implementation. International Journal of EPortfolio, 8(I), I 3. Retrieved from https://files.eric.ed.gov/fulltext/EJI I 77624.pdf

Creswell, J., Hanson, E., Clark Plano, V., \& Morales, A. (2007). Qualitative Research Designs: Selection and Implementation. The Counseling Psychologist, 35, 236-264.

Creswell, J.W. (20I2). Educational research: planning, conducting, and evaluating quantitative and qualitative research (4th ed). Boston: Pearson.

Donmoyer, R. (2006). Take my paradigm ... please! The legacy of Kuhn's construct in educational research. International Journal of Qualitative Studies in Education, 19(1), I I-34. https://doi.org/ 10.1080/095 I8390500450 I77

Dudovskiy, J. (20।8a). Axiology. Retrieved 30 December 20। 8, from Research-Methodology website: https://research-methodology. net/research-philosophy/axiology-2/

Dudovskiy, J. (2018b). Constructivism Research Philosophy. Retrieved 29 December 2018, from Research-Methodology website: https://research-methodology.net/research-philosophy/epistomology/constructivism/

Dyson, M. (2007). My Story in a Profession of Stories: Auto Ethnography - an Empowering Methodology for Educators. Australian Journal of Teacher Education, 32(I). https://doi.org/l0.1422I/ajte.2007v32n I.3

Ellis, C., Adams, T. E., \& Bochner, A. P. (20 I0). Autoethnography: An Overview. Forum Qualitative Sozialforschung / Forum: Qualitative Social Research, 12(1). https://doi.org/10.17169/fqs-12.1.1589

Freire, P. (1998). Pedagogy of freedom: Ethics, democracy, and civic courage. Lanham, MD: Rowman \& Littlefield.

Guba, E. G., \& Lincoln, Y. S. ( 1 982). Epistemological and methodological bases of naturalistic inquiry. ECTJ, 30(4), 233-252. https:// doi.org// 0.1007/BF02765 /85

Guba, E. G., \& Lincoln, Y. S. (2005). Paradigmatic Controversies, Contradictions, and Emerging Confluences. In N. K. Denzin \& Y. S. Lincoln (Eds.). In Yvonna S. Lincoln \& Norman K. Denzin (Eds.), The SAGE Handbook of Qualitative Research (4th ed., pp. 191-215). Thousand Oaks, CA: SAGE.

Hammersley, M. (20।8). What's wrong with ethnography?: methodological explorations. New York: Routledge.

Hart,S.L.( I 97 I).Axiology--Theory ofValues.Philosophy and Phenomenological Research, 32( I),29-4I.https://doi.org/I 0.2307/2 I 05883

Herr, K., \& Anderson, G. L. (20।4). The Action Research Dissertation:A Guide for Students and Faculty. SAGE Publications.

Holt, N. (2003). Representation, legitimation, and autoethnography: An autoethnographic writing story. International Journal of Qualitative Methods, 2(I). Retrieved from https://sites.ualberta.ca/ iiqm/backissues/2_l/html/holt.html

Inayatullah, S. (n.d.). Futures Studies:Theories and Methods. Retrieved 30 December 20 I8, from OpenMind website: https://www. bbvaopenmind.com/en/articles/futures-studies-theories-and-methods/

Ings, W. (20 I 7). Ings, W. (20 I 7). Disobedient teaching: Surviving and creating change in education. Otago University Press. New Zealand: Otago University Press.

Joslin, R., \& Müller, R. (2016). Identifying interesting project phenomena using philosophical and methodological triangulation. International Journal of Project Management, 34(6), I043-1056. https://doi.org/ I 0. I0 I 6/j.ijproman.20 I6.05.005

Kenyon, C., \& Hase, S. (200 I ). Moving from andragogy to heutagogy in vocational education. Proceedings of the 4th Annual Australian Vocational Education and Training Research Association (AVETRA) Conference, 8. 
Kivunja, C., \& Kuyini, A. B. (2017). Understanding and Applying Research Paradigms in Educational Contexts. International Journal of Higher Education, 6(5), 26. https://doi.org/I0.5430/ijhe.v6n5p26

Koshy, V. (2009). Action Research for Improving Educational Practice:A Step-by-Step Guide. SAGE.

Kuhn, T. S. (1970). The structure of scientific revolutions. In Foundations of the Unity of Science: Vol. 2. International encyclopedia of unified science (2nd ed.). Chicago: University of Chicago Press.

Mackinnon, A., \& Powell, B. (2008). Paradigms and Worldviews. In A. Mackinnon \& B. Powell (Eds.), China Calling: A foot in the global door (pp. 23-25). https://doi.org/l 0.1057/9780230594203_5

Mann, S., Eden-Mann, P., Smith, L., Ker, G., Osborne, P., \& Crawford, P.A. (2017). A Transformation Mindset as the Basis for Sustainable Community Development. In John Stansfield and Amber Frankland-Hutchinson (Ed.), Sustainably Yours: Community Development and a sustainably just future (pp. 59-72). Auckland: aPress,.

Mann, S., Ker, G., Eden-Mann, P., \& O 'Brien, R. (20।7). QUALIFIED TO SURF CHAOS: A SELF-DETERMINED DEGREE. Education -Scope: (Learning \& Teaching), 4, 24-38.

Mann, S., Ker, G., Eden-Mann, P., \& O'Brien, R. (2017a). Designing for Heutagogy: An Independent Learning Pathway Approach. Capable - Scope: (Flexible Learning), 2, 59-70. Retrieved from http://www.thescopes.org/assets/Uploads/Mann-ILP2.pdf

Mann, S., Ker, G., Eden-Mann, P., \& O'Brien, R. (20।7b). Designing for Heutagogy: An Independent Learning Pathway Approach. Capable - Scope: (Flexible Learning), 2, 59-70.

Mann, S., Ker, G., Eden-Mann, P., \& O'Brien, R. (2017c). Qualified to surf chaos: A self determined degree. Scope, Learning and Teaching(3), 24-38. Retrieved from https://www.thescopes.org/assets/Uploads/SCOPE-learn-teach-3-Web-4-Mann-et-al.pdf

Mezirow, J. (199|). Transformative Dimensions of Adult Learning. San Francisco, CA: Jossey-Bass

Michigan State University. (n.d.). Greek and Latin Roots: Roots. Retrieved 21 November 2018, from Michigan State University website: https://msu.edu/ defores I/gre/roots/gre_rts_afx2.htm

Mitchell, M., \& Egudo, M. (2003). A Review of Narrative Methodology [Data set]. https://doi.org/ I 0. I 037/e426492005-00 I

New Zealand Qualifications Authority. (2016). The New Zealand Qualifications Framework. NZQA.

O'Brien, R. (2016). The centralised development of elearning resources: a thesis presented in partial fulfilment of the requirements for the Masters of Education (Elearning) at Massey University, Manawatū, New Zealand. (Master of Education (eLearning), Massey University). Retrieved from https://mro.massey.ac.nz/handle/I0179/1 1703

O'Brien, R. (2018a). Learning Design - A response to develop learners as sustainable practitioners. Presented at the Association of Campuses Towards Sustainability, Adelaide Australia.

O'Brien, R. (20।8b). Social eduprenuership- an emerging professional framework for educators. Scope-Contemporary Research Topics, Flexible Learning(3), 38-40. Retrieved from https://www.thescopes.org/assets/Uploads/38-Scope-Flexible-Learning-3o-brien.pdf

O'Brien, R. (20 18c). Transformational Failure or Failing to Transform? Exploring Professional Futures, I 8. Dunedin: Otago Polytechnic.

O'Gorman, K., \& MacIntosh, R. (20I5). Research Methods for Business \& Management (2nd ed.). In The Global Management Series (2nd ed.). Retrieved from https://www.researchgate.net/publication/28I236523_Mapping_Research_Methods

Online Etymology Dictionary. (n.d.). evaluation | Origin and meaning of evaluation by Online Etymology Dictionary. Retrieved 21 November 2018, from Online Etymology dictionary website: https://www.etymonline.com/word/evaluation

Ormerod, R. (2006). The history and ideas of pragmatism. Journal of the Operational Research Society, 57(8), 892-909. https://doi. org/10.1057/palgrave.jors.2602065

Otago Polytechnic. (2016). Programme Document: OT5 105 Doctor of Professional Practice. Otago Polytechnic.

Patel, S. (20।5, July 15). The research paradigm - methodology, epistemology and ontology - explained in simple language [Blog]. Retrieved 30 December 20 I8, from Salma Patel- Research, Digital, UX and a PhD website: http://salmapatel.co.uk/academia/ the-research-paradigm-methodology-epistemology-and-ontology-explained-in-simple-language/

Posner, P. L. (2009). The Pracademic: An Agenda for Re-Engaging Practitioners and Academics. Public Budgeting \& Finance, 29(I), 12-26. https://doi.org/ 0.1 I I |/j. I540-5850.2009.00921.x

Ramos, J. (2002). Action Research as Foresight Methodology.Journal of Future Studies, 7(I), I-24. Retrieved from https://jfsdigital.org/ wp-content/uploads/20 I/06/07I-A0 I.pdf

Sousanis, N. (20I5). Unflattening (I st ed.). London: Harvard University Press.

Syed, M. (20।5). Black Box Thinking. London: John Murray.

Tait, A., \& Faulkner, D. (2016). Edupreneur: Unleashing Teacher Led Innovation in Schools (I st ed.). Melborn: John Wiley \& Sons.

Tuohy, D., Cooney, A., Dowling, M., Murphy, K., \& Sixsmith, J. (2013). An overview of interpretive phenomenology as a research methodology. Nurse Researcher, 20(6), 17-20. https://doi.org/ 10.7748/nr20 I3.07.20.6.17.e3 I5

Ültanır, E. (20I2). An epistemological glance at the constructivist approach: constructivist learning in Dewey, Piaget and Montessori. International Journal of Instruction, 18. 